\title{
Bodó László1: A polgári jog és a munkajog összehasonlítása az alapelvek tükrében
}

Debreceni Jogi Műhely, 2012. évi (IX. évfolyam) 4. szám (2012. október) 13-21.

A két jogág kapcsolatának definiálása nemcsak dogmatikai szempontból lényeges, hanem a konkrét jogalkalmazásra is kiható kérdés. A nem megfelelő válasz jogalkalmazási bizonytalanságokhoz, nehézségekhez vezethet. A polgári jog és a munkajog kapcsolata az alapelvek tükrében jól meghatározható, irányadó minden más lehetséges kapcsolódási ponthoz, illetve bizonyos tekintetben meg is elözi őket.

Az alaptételem az, hogy a munkajog önálló jogág ugyan (a szabályozás tárgya és szabályozás módszere erre predesztinálja), de nem lehet a polgári jogtól teljesen elszakítottként sem kezelni. A polgári jogból (közelebbről a kötelmi jogból) vált ki a speciális tárgya miatt, de a polgári jog, mint anyajog egyfajta "gravitációs középpontként" szolgál, amihez kapcsolódik nemcsak a munkajog, hanem a belőle kivált többi magánjogi jogág (pl. családjog). A munkajog "távolabb" kerül ugyan a "gravitációs középpontjától", a magánjog és a közjog határáig megy, de nem lépi azt át. Nem lehet azonban a munkajogot "tisztán" magánjogi jogágként sem meghatározni, hisz a szabályozás során számos szociális alapú közjogi elem érvényesül. A munkajog tehát egyfajta keresztülfekvő jogágként is kezelhető, amely egyszerre viseli a magánjog (elsősorban az alapvető elvek és az individuális munkajogra vonatkozó szabályok terén) és a közjog (kógens szociális alapú normák) egyes jellemzőit. (Mindezek alapján a munkajog a "vegyes szakjogok" csoportjába is kategorizálható. ${ }^{2}$ ) Noha a munkajog áttöri a klasszikus magánjog határait tárgyának jellegzetessége folytán, attól még a magánjog részét (is) képezi. Lévén a magánautonómia kifejeződési formája marad, ami a szerződéses elv bázisát képezi, s ez tipikusan a magánjogi jogviszonyok sajátja.

Az, hogy egy magánjogi jogviszonyban megjelennek közjogi elemek, nem rendkívüli. Mint ahogy a munkajog, illetve a többi vegyes jogág léte és felismerése folytán is kidomborodik, a jogági tagozódás a maga irrealisztikus tisztaságában markánsan csak az elméletben és a jogi oktatás szintjén jelentkezik. Az egyes jogágak a gyakorlatban összefonódnak és egymásra gyakorolt kölcsönhatásokkal fejtik ki jogi hatásukat. ${ }^{3}$ Úgy gondolom, a munkajogot dogmatikailag a magánjog részeként kell kezelni. Nem a munkajog az egyetlen terület, ahol a jogalkotó a kiszolgáltatottabb helyzetben lévő felet védő kógens normákat épít a jogviszonyba. A lakásbérleti jog szabályozásában is helyet kapnak szociális okokból a gyengébb fél védelmében a bérbeadót korlátozó rendelkezések, mégsem beszélünk a polgári jogtól (kötelmi jogtól) elkülönülő lakásbérleti jogról. ${ }^{4}$ (A lakások és helyiségek bérletéről szóló törvény bevezetése kifejezetten mögöttes joganyagává teszi a Ptk.-t.)

A munkaviszony szerződéses kötelem. Ez olyan vitathatatlan tény, amely a munkajog magánjogba való tartozását a jogtudomány akkor is megadja, ha ez a kodifikáció szintjén kifejezésre nem kerül. A tételes jog szintjén a Munka Törvénykönyve nem teszi a Polgári Törvénykönyvet generálisan mögöttes joganyagává, noha a munka jogviszonyai történetileg sokáig a polgári jog részét képezték. Nálunk szerencsésebb történelmi fejlödésü nyugateurópai országokban a jóléti állam koncepciójának megfelelően egy olyan polgári jogból kifejlesztett munkajogról beszélhetünk, amelyet noha számos közjogias intézmény átsző, mégis visszanyúl a polgári joghoz. ${ }^{5}$ A szocialista munka-kódexek ezzel szemben a polgári jogtól mereven elszakítva próbálták szabályozni a munkaviszonyokat. Ez maradéktalanul már akkor sem sikerült, s eleve kudarcra ítéltetett a két joganyag szoros összefüggése okán. A szocialista jog eme szemlélete azonban ma is érezteti hatását. 
Az alapelvek összevetése szempontjából alapvető fontosságú előkérdés, hogy miért válik ki a munkajog a polgári jogból (mi a munkajog tárgya és szabályozási módszere)?

A más részére végzett munkatevékenységek közül a munkaviszony elkülönül a szabályozásban a polgári jogtól, amit dogmatikailag azzal lehet igazolni, hogy a munkajog (ellentétben a polgári jogban szabályozott megbízástól vagy vállalkozástól) az önállótlan munkavégzés jogága. Másképpen megfogalmazva a munkajog tárgya a "függő" munka, és mint ilyen tradicionálisan szembeállítható a megbízási és vállalkozási típusú polgári jogviszonyokkal. A kérdés - ami a két jogág alapvető kapcsolatát is meghatározza - hogy miért szükséges a munkajogviszony realizálásához az egyik fél alárendeltsége, míg a polgári jogi viszonyokban nem? ${ }^{6}$ Másképpen: honnan eredeztethető a függőség?

Születtek elméletek, mint a gazdasági ${ }^{7}$ vagy a személyi függőség ${ }^{8}$ teóriája, melyek nem nyújtottak kellően megnyugtató választ, így szükségessé vált egy olyan elmélet kidolgozása, ami nem jogon kívüli tényezőkkel magyarázza a munkaviszony különállását a többi kötelmi jogviszonytól. Így az uralkodó tan szerint az elhatárolási ismérv az, hogy míg a vállalkozás és a megbízás esetében a szolgáltatás nyújtó fél egy előre meghatározott, konkretizált szolgáltatás teljesítésére vállalkozik, úgy a munkajogviszony esetén a szolgáltatás realizálása a jogviszony tartalma alatt (kötelező utasítások útján) és nem elöre történik. Ezért a polgári jogi jogviszonyokban mintegy kizárt, hogy a fogadó fél uralmi helyzetbe kerüljön, ellentétben a munkaviszonnyal, ahol ez fogalmi ismérv. ${ }^{9}$ Ezért eme felborult egyensúlyi állapot helyreállítása végett szükséges védőintézkedéseket beépíteni a jogviszonyba. Egy szociális jogállam - felismerve hogy a munkaszerződés alanyai nem egynemü szereplök a gazdasági forgalomban - az újonnan megjelenő szociális jogok által keletkező kötelezettsége folytán is kógens szabályok elöírásával relatíve korlátozza a munkaadói jogokat. ${ }^{10}$ Szemben a polgári joggal, ahol teljes mértékben a diszpozitivitás érvényesül és a törvény "az azonos minöségü jogalanyok minimálisan elvárható objektivizált magatartási szabályait rögzíti."11

A munkajog tehát egy felborult egyensúlyi állapotban lévő jogviszonyt szabályoz, felismervén azt is, hogy alanyai gyakran a gazdasági forgalom nem egynemü szereplöi. Az, hogy miként próbálja a munkajog helyreállítani az egyensúlyi állapotot, visz a szabályozás módszere felé. Így az egyik lehetőség, hogy direkt módon a gyengébb felet védő kógens normákat emel kötelezően a jogviszonyba. Ez azonban nem eredményezi a polgári jogtól való elválást, nem feltétlenül ellentétes a kötelmi jog alapvető elvével a szerződéses elvvel, hisz a munkaviszonyban a felek akaratautonómiájának legteljesebb érvényesülése pontosan így biztosítható. Míg a kötelmi jogviszonyok természetüknél fogva egyenlően kétoldalúak, úgy a munkaviszonyt azzá kell tenni.

Ha a munkajogra a magánjog részeként tekintünk, akkor az is természetesnek tűnhet, hogy a magánjog elvei (melyek a polgári jogot is áthatják) a munkajogban is érvényesülnek. Találó az a megállapítás hogy, " a munkajogban nem a magánjogi elvek érvényesülését, hanem egyes területeken azok hiányát kell indokolni". ${ }^{12}$ A kérdés az, hogy mi okozza a polgári jogi elvek eltérő vagy egyáltalán nem történő érvényesülését a munkajogban?

Az eltérések okai egy magasabb "szinten" gyökereznek: az alkotmányos elvek szintjén. Ez képezi az összehasonlítás első fokát. A két jogágat meghatározó elvek egy része alkotmányos jelentőségü - nevezzük akár alapjognak vagy alkotmányos értékü elvnek őket. Ezek összecsapása a munkajog területén az alapjogi kollízió, aminek egyenes következménye adott magánjogi elvek eltérő munkajogi érvényesülése.

A munkajogot a szociális eszme és a második generációs jogok megjelenése és érvényesülése hívta életre. A konfliktust itt az okozza, hogy a klasszikus magánjogi alapelvek az első 
generációs jogokon nyugszanak, amelyek összességében a "szabadság" jelzővel illethetőek és a be nem avatkozást hirdetik. A polgári jogra levetítve ez az akaratautonómia legteljesebb érvényesülése és a felek egyenlősége, amely a be nem avatkozással biztosítható. A szociális jogok által azonban (amelyek áthatják a munkajogviszony szabályozását) az állam felismerte, hogy pusztán a szabadságjogokkal az egyenlőség bizonyos esetekben nem biztosítható. ${ }^{13} \mathrm{~A}$ munkaviszonyra levetítve ez azt jelenti, hogy a munkavállaló egzisztenciális védelme érdekében a munkáltató akaratautonómiáját bizonyos mértékig korlátozni kell, míg a munkavállalói oldalhoz többletjogokat kell rendelni, mert így lesznek a felek egyenlők és a szabadságjogok is csak ezen a talajon érvényesülhetnek. Közelebbröl három alkotmányos alapelvet emelek ki, amelyek alapvetően meghatározzák a munkajog szabályozását: a foglalkozás és a munkahely szabad megválasztásához, az emberi munkafeltételekhez és az igazságos jövedelemhez füződő jogot. Közös jellemzőjük, hogy "másodgenerációs" szociális jognak minősülnek és az esélykülönbözőségek kiegyenlítésére törekednek, szemben az "első generációs" szabadságjogokkal. ${ }^{14}$ Ezen a ponton nem lehet szó nélkül elmenni a munkához való jog, mint szociális jog alapjogi mivoltának kérdése mellett. Hiszen ha nem alapjog, nem is állhat kollízióban. Az Alkotmánybíróság a korábbi Alkotmány értelmezésében, az Alaptörvény pedig már szövegezésében is ("törekszik megteremteni") ${ }^{15}$ államcélként definiálja. A munkához való jogot azonban meg lehet "fogni" az intézményvédelmi oldalról: az állami kötelezettségvállalást megfelelö foglalkozáspolitika kialakítására. Ily módon a munkához való jog (mint szociális jog) testet ölt alanyi jogként kikényszeríthető normák formájában. Ha alkotmányjogi megközelítésben alapjognak nem is minősül ugyan, de olyan értéket fejez ki, mely az Alaptörvényben és a szabályozásban a szociális eszme hatására megjelenik (tulajdonképpen ez hívta életre a munkajogot is), s mint ilyen alkotmányos szintü elvnek nevezném, amely ütközhet az alkotmányban megjelenő más alapvető értékekkel.

A szociális jogok azonban nem okoznak törést az alapjogok rendszerébe, lévén mind a klasszikus alapjogok, mind a szociális jogok az emberi méltóság érvényesülését biztosítják, amely magában hordozza az egyenlőség követelményét is. ${ }^{16}$ Az első generációs alapjogok az egyenlőség és a mellérendeltség premisszáján születtek és nyugszanak. Azt az ideát testesítik meg, hogy szerződéses kapcsolatok egyenlő helyzetben lévő felek kölcsönös akaratautonómiáján nyugszik. A második generációs jogok megjelenése azonban a szerződéses kapcsolatok viszonyában azt a felismerést jelentette, hogy ténylegesen nem minden esetben valósul meg a felek mellérendeltsége. Az önállótlan munkavégzésre irányuló jogviszonyokban, az egyik fél - a munkavállaló - egzisztenciálisan könnyen kiszolgáltatottá válhat, ezért nincs az önrendelkezés azon fokán, amit pont az első generációs jogok kívánnának meg. Ezért a polgári jogi szerződéses viszonyokkal ellentétben - ahol a felek magánautonómiája szinte teljes - a munkaviszonyok terén szükséges az egyik fél - a munkáltató - önrendelkezésének bizonyos szintü korlátozása, a már felsorolt főbb szociális alapjogok érvényesítése végett.

Ahogyan a második generációs jogok (köztük a szociális jogok) megbolygatják az alapjogok addigi rendszerét, úgy kezd elkülönülni a munkajog és válik kétségessé a magánjogi elvek alkalmazhatósága eme új jogágban. De minthogy az alapjogok egységes rendszere se törik meg, a munkajog sem válik ki a magánjogból. ${ }^{17}$

A vizsgálat második szintjén azt kell górcső alá venni, hogy a magánjogi elvek kifejezésre juttatják-e a szociális jogállammal szemben támasztott követelményeket vagy legalábbis neme ellentétesek vele. Amennyiben képesek kifejezni a munkajog célját: egy felborult egyensúlyi állapot helyreállítását, úgy a munkajog részévé válnak, a szabályozásban 
érvényesülnek. Innen azt vizsgálom, hogy a magánjogi (polgári jogi) alapelvek miként érvényesülnek a munkajogban. ${ }^{18}$ Azonban az alapelveket két részre bontom: megkülönböztetem a deklaratív alapelveket, amelyek "Elveknek" nevezek és operatív alapelveket, amelyeket "Szabályoknak". Ez az elosztás némely alapelv tekintetében viszonylagos, azonban a fő elhatárolási ismérv, hogy "szabályok" (pl. együttmüködési kötelezettség) önmagukban is alkalmasak lehetnek egy jogvita eldöntésére, míg az "Elvek"(pl. szerződési szabadság) nem. Az elvek jogpolitikai tendenciákat, célkitüzéseket jelölnek ki. Míg a szabályok kivétel nélkül megjelennek az írott jogban, a jogviszony egészét átható magatartási szabályként funkcionálnak, addig az elvek jellemzően nem jelennek meg írásban, de ha meg is jelennek önmagukban nem alkalmasak a jogvita eldöntésére. Az elvek elsősorban a jogalkotónak, míg a szabályok a jogalkalmazónak nyújtanak orientációt.

Az elvek sorában a magánjog egészét átható alapelvek - minthogy elősegítik a szociális jogállammal támasztott követelményeket - a munkajogban is érvényesülnek. Ide sorolandó az autonóm mozgástér védelme, igazságosság, ésszerüség, jogbiztonság, értelmezési alapelv. Az "elvek" sorában is ezek azok, amelyek leginkább absztraktak, a maguk elvont nagyságaiban léteznek leginkább.

Minthogy a munkajog a polgári jogon belül is mind dogmatikailag mind történetileg a kötelmi joggal áll szoros viszonyban, vizsgálni kell a kötelmi jogi alapelvek munkajogban való érvényesülését.

A szerződéses szabadság jelenti téma szempontjából az egyik leglényegesebb elvet.

A szerződéses szabadság nem alapjog, de több alapjog érvényesülését is biztosítja. Biztosítja egyrészt a vállalkozás szabadságát, amely jelen téma szempontjából a munkáltatói minőséget fémjelzi. Ugyanakkor garantálja az önrendelkezés érvényesülését, ami az emberi méltóságból következik és a munkavállalói oldalon (is) jelentkezik. A munka világában a problémát az jelenti, hogy munkáltató az általában meglévő hatalmi egyenlőtlenségek folytán képes a magánautonómiáját tényleges érvényesíteni, míg a munkavállaló nem feltétlenül. A munkajog területén ez megkerülhetetlen alapjogi kollíziót indukál, ami szükségképpen eredményezi, hogy ez az elv eltérő tartalommal és szinten érvényesül a munkajogban, mint a klasszikus magánjogi jogágakban. Lévén, ha kettejük találkoznak az egyenlőség hiányában a privátautonómia a gyengébb fél oldalán sérül, ezért a munkaviszonyban a szerződéses elv eltérő (közhatalmi eszközökkel korlátozott) érvényesülése pont azt az egyenlőségi állapotot lenne hivatott megteremteni, ami a klasszikus magánjogi jogviszonyokba adott és amit esetükben pont a szerződéses elv ilyetén való korlátozása borítana fel.

A szerződéses szabadság tehát kezelhető úgy is, mint egy olyan alkotmányos elvi szintü követelmény, ami az egyenlőség premisszáján nyugszik. A felek magánautonómiáját hivatott a lehető legteljesebb mértékben érvényesíteni. Az érvényesítés módja azonban más a klasszikus magánjogi viszonyokban, mint a munkajogviszonyban. Hiszen míg más kötelmekben az elv érvényesüléséhez az állam beavatkozásának hiánya, passzivitása kell, addig a munkajogban pont a - megfelelő mértékü - állami intervenció szükségeltetik ugyanehhez. Az alapvetés az, hogy a szerződéses szabadság érvényesülésének feltétele a felek mellérendeltségen alapuló viszonya. A munkajogviszony fogalmi sajátja a függőség, ezért a szerződéses szabadság érvényesüléséhez az kell, hogy a jogalkotó a gyengébb fél védelmében egyensúlyi helyzetet teremtsen, mintegy helyreállítsa azt és megteremtse a szerződéses elv alapját. ${ }^{19}$

A szerződéses szabadság főszabályszerüen azt jelenti, hogy a felek akarata nincs megkötve. Ez az akaratszabadság négy irányban jelentkezhet: ${ }^{20}$ Szerződéskötési szabadság, partnerválasztás szabadsága, típusválasztás szabadsága és a diszpozitívitás elve. A 
munkajogviszonyban a szerződési szabadság elve erősen korlátozottan érvényesül csupán. A munkaszerződés tartalma sohasem egyenlő a munkajogviszony tartalmával. Leginkább a típusválasztás szabadsága és a diszpozitivitás elve csorbul. Amennyiben a tevékenység a munkaviszonyra jellemző sajátosságokat mutatja, úgy a jogalkotó az átminősítést biztosítja. Jellemzően azért, mert így látja a jogalkotó biztosítottnak a gyengébb fél védelmét, lévén ehhez a jogviszonyhoz kapcsolódnak a munkavállalót védő szociális tartalmú kógens normák. Mondhatni tehát, hogy a munkáltató és a munkavállaló pozícionális kiegyenlítésére való törekvésnek az áldozatává esik a szerződéses elv a munkajogi jogviszonyokban jelen állapotok között.

Kérdés ezek után, hogy állítható-e egyáltalán az, hogy érvényesül a szerződéses elv a munkaviszonyban. Tekintve, hogy a munkajog a magánjog része, és a szerződéses elv a magánjog egyik alapvető fontosságú elve, ezért az ideális válasz az lenne, hogy igen. Igen, de a munkajogviszony tekintetében speciálisan: egy magasabb szinten - a kollektív önrendelkezés szintjén. Tulajdonképpen ezt a szerepet kellene betöltsék a kollektív megállapodások. Ha a kollektív megállapodások be tudnák tölteni maradéktalanul azt a munkerö-piac alakítási funkciót, mint amit a jogalkotói idea szánt neki eredetileg, akkor csökkenthető lenne az Mt. kogenciája, ami automatikusan azzal a következménnyel járna, hogy a szerződéses elv kisebb mérvü korlátozása mellett egyensúlyi pozíció alakulhatna ki, tulajdonképpen a piac önszabályzó mechanizmusára bízva. Ez már egyértelmüen a magánjogi jogviszonyok sajátja. Persze ez nem jelenti, hogy pusztán piaci mechanizmusok igazságosságot szülnének. Az állami beavatkozás a - munkaviszony sajátos tárgyából adódóan - mindig szükséges lesz olyan közvetlen eszközök útján is, mint például szociális megfontolású kógens normákat a jogviszony részévé tenni. Törekedni kell azonban, hogy a magánjog tradicionális eszközeit állítsa minél inkább a cél eléréséhez, és annyiban nyúljon a közjog eszközeihez, amennyiben ez feltétlenül szükséges. Ez egy hangsúlyeltolódást jelent: a munkajognak a közjog és magánjog határáról, utóbbi felé elmozdulását. Minél nagyobb mérvü az elmozdulás, annál teljesebben érvényesül a szerződéses elv is munkajogban.

A szabályoknak minősülő alapelvekre áttérve további problémával szembesülünk. Tekintve hogy az elvekhez képest a szabályok szerepe a jogalkalmazás során konkrétabb: önállóan alkalmasak lehetnek egy jogvita eldöntéséhez. Ezért itt már bizonytalanságot okozhat, hogy a kodifikáció szintjén az Mt. nem rendeli generálisan mögöttes szabállyá a Ptk.-t. A tételes jog síkján bizonytalan, hogy egyes Ptk.-ban szabályozott intézmények mennyiben alkalmazhatóak, ha az Mt. azokra közvetlenül nem utal, vagy nem veszi át egy az egyben. Igaz ez azokra a "szabályokra" is, amelyek a Ptk. bevezető rendelkezéseiben illetve a szerződéstan általános részében kapnak helyet és a jogok gyakorlásának és kötelezettségek viselésének alapvető kritériumait adják. Ez a kérdés akkor kerül elö, amikor egy tényállás kapcsán joghézag mutatkozik. Az elvekhez hasonlóan elmondható, hogy a bírói gyakorlat a munkajoghoz érti azon polgári jogi szabályokat is, amelyek megfelelnek a szociális jogállam által támasztott követelményekkel, ezáltal az Mt. intézményeivel nem ellentétesek. Mintegy betölti azt az ürt, ami a hatályos Mt. és Ptk. szabályozása folytán keletkezett.

Nem merül fel a probléma azon szabályok tekintetében, amit az Mt. párhuzamosan szabályoz a Ptk-val, néhol szinte szóról szóra. Itt a problémát legfeljebb a felesleges megkettőzés jelenti. Ide tartozik az együttmüködési kötelezettség, a jóhiszeműség és tisztesség követelménye, joggal való visszaélés. Bár eme általános magatartási szabályok minden szerződéses kapcsolatban kiemelkedő jelentőséggel bírnak, mégis talán a munkaviszony az, ahol ezek tényleges érvényesülése a legfontosabb. Pusztán abból adódóan, hogy a munkaszerződés jellemzően tartamjogviszonyt keletkeztet, amely ráadásul nem mentes a személyes elemektől 
sem. Ezen jellemzői fokozottan magukba hordozzák a vitás helyzetek kialakulását, amelyek megelözését szolgálnák ezen szabályként érvényesülő elvek érvényesülése, betartása.

A 2012. évi I. új Munka Törvénykönyve révén az elvárhatóság mércéje a polgári jogi jogviszonyokhoz hasonlóan a munkajogviszonyban is általánossá lett. Érinti a változás a munkajogi kárfelelősségi jogviszony szabályozását is. A törvény szövege ugyan még vétkesség fogalmát használja, de tartalmában mégis a felróhatósággal. "A munkavállaló a munkaviszonyból származó kötelezettségének megszegésével okozott kárt köteles megtériteni, ha nem úgy járt el, ahogy az adott helyzetben általában elvárható." [179.§(1)] Ugyanezen szakasz harmadik bekezdése pedig így szól: "A kártérités mértéke nem haladhatja meg a munkavállaló négyhavi távolléti dijának összegét. Szándékos vagy súlyosan gondatlan károkozás esetén a teljes kárt kell megtériteni." Összességében az látszik, hogy a munkavállaló felelőssége szigorodik. A jogviszony tartalmában az eddig "tőle elvárhatósághoz" képest a felróhatóság adott helyzetben "általában elvárhatósága" - mely a cselekmény objektív, a "jó és gondos családapa" magatartási mércéjét teszi zsinórrá egyértelmúen szigorúbb. A bírói gyakorlatra vár ugyanakkor annak az egységes kimunkálása, hogy hol húzza meg azt a határt, amely még összeegyeztethető a szociális jogállam támasztotta követelményekkel. A polgári jog szempontjából kicsit furcsának tünik, de munkajogi megközelítésben és azon eltérő tárgyából folyóan indokolt lehet a szándékos és a súlyosan gondatlan vétkességi fogalmak megjelenése a felróhatóság mellett. Tekintettel arra, hogy az új Mt. a felelősség bázisává az elvárhatóságot tette, ezen vétkességi formulák szükségképpen el kell hogy veszítsék az eredetileg a büntetőjogból átvett tisztán szubjektív jelentéstartalmat. Azaz a felróható magatartás is lehet szándékos és súlyosan gondatlan amikor teljes kárt meg kell téríteni, egyéb esetekben a munkavállaló kártérítési kötelezettségének mértéke ex lege korlátozott. A polgári jogban - lévén a teljes reparációs elven nyugszik - ezen kategóriák vizsgálata igazából fel sem vetül, de a munkajogban - amely a szociális állam ideológiájával még mindig áthatott - a felelősséget korlátozni kell.

Az új Mt. elvárhatóságot tehát alapelvi szinten rögzíti, és igyekszik tartalommal is megtölteni. Ez egy jelentős lépés, amely szorosabbra füzi a munkajog és polgárjog (jogtudományban amúgy is meglévő) kapcsolatát. A felelősség tekintetében ez azt is jelenti, hogy míg eddig a prevenciós elv volt a domináns a munkajogban, ezt követően elmozdulást figyelhetünk meg a reparációs elv irányába, ami egyértelmüen a polgári jog sajátja.

Nem sérülnek szükségképpen a szociális állam által - alkotmányos szintü elvek mentén kifejezésre jutó - érvényesítendő kritériumok sem. Garanciális biztosítékai ennek többek között, hogy továbbra is a munkáltatót terheli a bizonyítási kötelezettség [Mt. 179.§ (2)], a felelősség mértéke ex lege korlátozott [179.§ (3)]. Mindez azzal együtt igaz, hogy nagy hangsúly van az általában elvárhatóság minimális szintjének meghatározásán, ami elsősorban a gyakorlatra vár.

Az új Mt.-nek köszönhetően az korábbiakhoz képest szintén mélyebben érvényesülni látszik egy jelentős operatív elv: a clausula rebus sic stantibus. A hatályos szabályozást megelőzően akkor volt alkalmazható, ha egy - egy intézmény között az Mt. megteremtette a kapcsolatot a Ptk.-val (pl. versenytilalmi megállapodás, tanulmányi szerződés). Most a jognyilatkozatok címü fejezetben, azon belül is a kötelezettségvállalás cím alatt található az elv egy jelentős megnyilvánulása: "A kötelezettségvállalás a jogosult terhére módositható vagy azonnali hatállyal felmondható, ha a jognyilatkozatot tevö körülményeiben a közlést követöen olyan lényeges változás következett be, amely a kötelezettség teljesitését lehetetlenné tenné vagy aránytalan sérelemmel járna." [16.§ (2)] 
Tekintettel a munkajogviszony felborult egyensúlyi állapotára, ez elsősorban a munkavállalói pozíció erősítésére alkalmas szabálynak tűnik. A clausula rebus sic stantibus szabálya ebben az esetben azt jelenti, hogy ha a jognyilatkozat megtétele (kötelezettségvállalása) után a munkavállaló körülményeiben olyan lényeges változás áll be, amely miatt a kötelezettség nem teljesíthetö, úgy mentesülhet a kötelem alól.

Meglátásom szerint ezen elv ilyetén való érvényesülése az olyan tartós és speciális tárgyú jogviszonyokban, mint a munkaviszony indokolt. Hiszen nem csak összeegyeztethető a szociális jogállam által megkívánt követelményekkel, hanem többek között ezzel a szabállyal is biztosíthatóak. A clausula rebus sic stantibus ezáltal tulajdonképpen egy méltányos munkavállalói érdek eseti elismerése, amelynek természetes korlátját képezné az elvárhatóság és ésszerüség magánjogi alapelve.

A téma szempontjából azok az elvek, melyek speciális tárgyából adódóan kifejezetten a munkaviszonyban jelennek meg markánsan (pl. munkáltató jogos gazdasági érdekeinek védelme) nem képezik összehasonlítás alapját. Nem úgy az egyenlő bánásmód követelménye. Az átfogó antidiszkriminációs törvény lévén érvényt kap a munkajogviszonyban, illetve azon polgári jogi jogviszonyokban, ahol nem füződik erősebb érdek a magánautonómia háborítatlanságához. Az egyenlő bánásmód azért rendhagyó, mert eddig az volt megfigyelhető, hogy a munkajog megjelenésekor a klasszikus magánjogi elvek először a munkajog szolgálatába álltak, majd kifejezetten olyan tartalmat vettek fel, ami a szociális jogállam követelményeinek megfelel, s később még az is megtörtént, hogy egy mélységileg először munkajogban érvényesülő alapelv (egyenlő bánásmód) hatott vissza a polgári jogra.

A munkajogviszonyban a fennálló tényleges hatalmi egyenlőtlenségek miatt a munkavállaló nem tudja a privátautonómiáját érvényesíteni, ezért az egyenlő bánásmód követelménye ebben a jogviszonyban fokozott jelentőséggel bír.

A munkajogviszonyban a probléma gyökere az, hogy a munkáltató abban érdekelt, hogy a számára legértékesebb munkaerőt foglalkoztassa (tovább), míg a munkavállaló abban, hogy egzisztenciális biztonságát minél hosszabb ideig biztosítsa a munkaviszony keretei között. A kor, a nem, az egészségi tényezők, az anyaság, a terhesség, a fogyatékosság többek között mind olyan tényezők lehetnek, amelyek hátrányt jelenthetnek a munkavállaló számára. ${ }^{21}$

A szociális jogállam ideológiájából következik és az alkotmányos alapjogként érvényesülö munkajogi alapelvekből, hogy az államnak védelembe kell vennie a munkavállalót, $\mathrm{s}$ ez szükségképpen jár a munkáltató magánautonómiájának és ezzel együtt a szerződési szabadság korlátozásával.

2003. évi CXXV. az egyenlő bánásmódról és az esélyegyenlőség előmozdításáról szóló törvény (továbbiakban: Ebtv.) ennek megfelelően meghatározza a diszkrimináció egyes formáit.

Az egyenlő bánásmód alapelvi követelménye először markánsan a munkajogban jelent meg, $\mathrm{s}$ igaz már a korábbi szabályozás is tartalmazott kiutalást a munkavégzésre irányuló egyéb jogviszonyokra (megbízás, vállalkozás), ez egyértelművé az átfogó antidiszkriminációs törvény megalkotásával (az egyenlö bánásmód követelményének általánossá tételével) vált. Természetesen a polgári jog alanyai az Ebtv.-t megelőzően sem voltak teljesen védtelenek köszönhetően a Ptk. 76.§-ának. ${ }^{22}$ Mára az Ebtv. révén az egyenlő bánásmód követelménye az emberi méltóságból, mint alkotmányos értékből következik, s immár intézményi szinten is egyformán érvényesül minden jogviszonyban. Vitathatatlan azonban, hogy a munkaviszony tekintetében - ahol a munkavállaló egzisztenciálisan kiszolgáltatott - kiemelt jelentőséggel bír. 
Mindent összevetve megállapítható, hogy a munkajogi elvek és a polgári jog elvek alapvetően egy tőröl fakadnak. Gyakran pont a magánjogi elvek mentén realizálódnak a munkajogban a szociális jogállam által támasztott követelmények. Ahol esetleg eltérés van, az is pont eme követelmények miatt adódik, lévén csak eltérö tartalommal biztosítható. Legkritikusabb pont a szerződéses szabadság elve. Ez szükségképpen korlátozás alá kerül, de fontos az egyensúly megtartása: egyszerre biztosítani a vállalkozás szabadságát és a munkavállalók egzisztenciális biztonságát.

\section{Felhasznált irodalom}

- PRUGBERGER Tamás: Európai és magyar összehasonlító munka - és közszolgálati jog, Complex Kiadó, Budapest, 2006

- KENDERES György: A munkaszerződés hazai szabályozásának alapkérdései, Novotni Alapítvány, Miskolc, 2007

- PRUGBERGER Tamás: Az új Ptk és a munkajogi szabályozás különös tekintettel az egyéni és a kollektív munkaszerződésekre In: Munkajog és a polgári jog kodifikációs és funkcionális összefüggései, sz: Manfred Ploetz és Tóth Hilda, Novotni Kiadó, Miskolc, 2001

- KISS György: Az új Ptk. és a munkajogi szabályozás, különös tekintettel az egyéni munkaszerződésekre In: Munkajog és a polgári jog kodifikációs és funkcionális összefüggései, sz: Manfred Ploetz és Tóth Hilda, Novotni Kiadó, Miskolc, 2001

- KISS György: Alapjogok kollíziója a munkajogban, Justis Bt., Pécs, 2010

- KISS György: Munkajog a közjog és a magánjog határán - egy új munkajogi politika kialakulásának szükségessége, Jogtudományi közlöny, 2008. (63. évf.) 2. szám

- LEHOCZKYNÉ KOLLONAY Csilla: Alkotmányos alapelvek a munkajogi szabályozásban in: Ünnepi tanulmányok, Munkaügyi igazgatás, munkaügyi bíráskodás Radnay József 75. születésnapjára, sz: Cúcz Ottó és Szabó István, Bíbor Kiadó, Miskolc, 2002

- KISS György: A szerződéses szabadság átalakulása a munkajogban az alapjogok tükrében in: Ünnepi tanulmányok, Munkaügyi igazgatás, munkaügyi bíráskodás Radnay József 75. születésnapjára, sz: Cúcz Ottó és Szabó István, Bíbor Kiadó, Miskolc, 2002

- BÍRÓ György: Kötelmi jog, Novotni Alapítvány, Miskolc, 2006

\section{Jogszabályok}

- Magyarország Alaptörvénye

- 1959. évi IV. törvény a polgári törvénykönyvről

- 2012. évi I. törvény a munka törvénykönyvéröl

\footnotetext{
${ }^{1} \mathrm{PhD}$ hallgató, DE-ÁJK.

${ }^{2}$ PRUGBERGER Tamás, Európai és magyar összehasonlitó munka - és közszolgálati jog, Complex Kiadó, Budapest, 2006. 44. oldal

${ }^{3}$ KENDERES György, A munkaszerződés hazai szabályozásának alapkérdései, Novotni Alapítvány, Miskolc, 2007, 25. oldal
} 
${ }^{4}$ PRUGBERGER Tamás, Az új Ptk és a munkajogi szabályozás különös tekintettel az egyéni és a kollektiv munkaszerzödésekre, In: Munkajog és a polgári jog kodifikációs és funkcionális összefüggései, sz: Manfred Ploetz és Tóth Hilda, Novotni Kiadó, Miskolc, 2001, 77. oldal

${ }_{6}^{5}$ PRUGBERGER Az új Ptk és a munkajogi szabályozás..., id. mü 73-74. oldal

${ }^{6}$ KISS György, Az új Ptk. és a munkajogi szabályozás, különös tekintettel az egyéni munkaszerzödésekre, In: Munkajog és a polgári jog kodifikációs és funkcionális összefüggései, sz: Manfred Ploetz és Tóth Hilda, Novotni Kiadó, Miskolc, 2001, 198. oldal

${ }^{7}$ gazdasági függőség elmélete alapján a munkavállaló gazdasági okokból kiszolgáltatott, és munkaerejét e kényszerből bocsátja a munkáltató rendelkezésére s ez kerül kifejezésre a kettejük jogviszonyában is.

8 a személyi függőség elmélete, amely a munkajogviszony "személyiségi-közösségi" jellegét hangsúlyozza. A felek jogviszonya két pilléren nyugszik: a munkavállaló hűségkötelezettségén és a munkaadó gondoskodási kötelességén.

${ }^{9}$ KISS György, Alapjogok kolliziója a munkajogban, Justis Bt., Pécs, 2010, 30. oldal

${ }^{10}$ KISS Az új Ptk. és a munkajogi szabályozása..., id. mủ 200-202. oldal

${ }^{11}$ KISS György, Munkajog a közjog és a magánjog határán - egy új munkajogi politika kialakulásának szükségessége, Jogtudományi közlöny, 2008. (63. évf.) 2. szám , 74. oldal

${ }^{12}$ KISS Az új Ptk. és a munkajogi szabályozás..., id. mü 193. oldal

${ }^{13}$ LEHOCZKYNÉ KOLLONAY Csilla, Alkotmányos alapelvek a munkajogi szabályozásban, In: Ünnepi tanulmányok, Munkaügyi igazgatás, munkaügyi bíráskodás Radnay József 75. születésnapjára, sz: Cúcz Ottó és Szabó István, Bíbor Kiadó, Miskolc, 2002, 281. oldal

${ }^{14}$ LEHOCZKYNÉ id. mü 278. oldal

15 Magyarország Alaptörvénye, Szabadság és Felelősség, XII. cikk (2) bek.: "Magyarország törekszik megteremteni annak feltételeit, hogy minden munkaképes ember, aki dolgozni akar, dolgozhasson."

${ }^{16}$ KISS György, Alapjogok kolliziója a munkajogban, Justis Bt., Pécs, 2010, 41. oldal

${ }^{17}$ KISS Az alapjogok... id. mü 559. oldal

${ }^{18}$ KISS Az új Ptk. és a munkajogi szabályozás..., id. mủ 195. oldal

${ }^{19}$ KISS György: A szerzödéses szabadság átalakulása a munkajogban az alapjogok tükrében, In: Ünnepi tanulmányok, Munkaügyi igazgatás, munkaügyi bíráskodás Radnay József 75. születésnapjára, sz: Cúcz Ottó és Szabó István, Bíbor Kiadó, Miskolc, 2002, 266. oldal

${ }^{20}$ BÍRÓ György, Kötelmi jog, Novotni Alapítvány, Miskolc, 2006, 225 - 235. oldal

${ }^{21}$ KISS Alapjogok... id. mü 317. oldal

22 a Polgári Törvénykönyvről szóló 1959. évi IV. törvény 76.§-a alapján "a személyhez füzödő jogok sérelmét jelenti különösen az egyenlö bánásmód követelményének megsértése, a lelkiismereti szabadság sérelme és a személyes szabadság jogellenes korlátozása, a testi épség, az egészség, valamint a becsület és az emberi méltóság megsértése." 